\title{
Developing the Students' Reading Comprehension through Interactive Approaches by Using Short Stories (An Experimental Research at South Aceh Polytechnic)
}

\author{
Hasbainia $^{a, 1}$, Amsar Yunan ${ }^{a, 2}$, Asmaidi $^{a, 3}$ \\ ${ }^{a}$ Polytechnic of South Aceh, Merdeka Street, Komplek Reklamasi Pantai, Tapaktuan city, 23751, Indonesia \\ 1'hasbainibean@gmail.com, ${ }^{2}$ amsar@poltas.ac.id, ${ }^{3}$ asmedmat@gmail.com
}

\section{ARTICLE INFO}

Article history:

Received

Revised

Accepted

Keywords:

Reading Comprehension, Short Story And

Interactive Approach.

\section{ABSTRACT}

This research was conducted to see the effectiveness of using short stories in teaching reading comprehension. The teaching model was used an interactive approach to be developed the reading skills of second semester students at the Department of Computer Engineering, South Aceh Polytechnic. The reading ability of students was explored and to be found the right teaching model, then the aspects of the ability to be seen was understanding the meaning of words, sentence intentions, information, problems, opinions, recommendations, sentence structure, analysis and communication and student responses after the application of the teaching model in the classroom. After treatment, there was an increase in students' reading comprehension skills especially in the experimental class after using short story teaching materials with interactive approach teaching models to obtain an average value of pre-test $=55$, and post-test $=77.67$. Whereas in the control class only got a pre-test value $=49,64$ and post-test $=67,86$. Then there was a significant difference in the scores of the two classes in the post-test scores $(77,67-67,86)$ namely 9,81. Meanwhile, from questionnaire data, $87 \%$ of students responded very well and the remaining $13 \%$ responded well to the use of short stories with interactive approach teaching models. As well as answering enough options and less as much as $0 \%$. From the responded above, which has helped develop student confidence, collaboration, self-ability and group work. Of course this research was far from perfection and needs to be improved in the future with other teaching methods, while still providing motivation to students to continue to be improved their learning, especially reading skills. So from the results of this simple study it can be recommended that, the use of short stories in teaching comprehension reading with interactive approach models got a significant increase in students' ability in reading comprehension than conventional learning models.

Copyright (C) 2020 Politeknik Aceh Selatan. All rights reserved.

\section{Introduction}

English is an international language used to communicate between countries and the importance of English has required each country to include it in their educational curriculum which is then taught in elementary schools to tertiary institutions, and even many countries applied English as the language of instruction in their world of education. This was done to familiarize their students with English itself, because apart from being a communication tool, English was also used in knowledge books, modules, literature, technology, magazines and newspapers which contain a lot of science 
and technology and various information that must be understood as supporting education and daily activities.

There are four abilities in English, namely writing, reading, speaking and listening, but here the writer will be focused only on reading skills only, where students will be introduced to various topics related to reading such as main ideas, inference, vocabulary in context, reference, fact, opinion, purpose and tone, where the subject was so that students were more familiar with it and aimed to train students with a variety of reading skills to obtain information in general or specifically from the material provided. So they are able to multiply and to get knowledge from the text.

Where, the readers bring various information, knowledge, emotional, experience, and culture from the printed book, and then make predictions precisely, and the readers interpret it [1]. The contribution of readers who make predictions and process information, this means the reader interacts with the text to predict what they will read. In this situation, the reader was processed all the information in the text and then translated the intent to be conveyed in various media.

And then understanding is a strategic process in which the reader builds or determines the meaning of a text by using the instructions in the reading and purely according to the ability of knowledge they have [2]. From these references, it can be concluded that reading comprehension was an effort where the message was translated the reader by actively thinking about what he has read and the lecturer certainly provides and prepares teaching materials that are familiar with the daily lives of his students. In this research questions, the researcher makes the following questions;

a) Are there significant differences in improving reading comprehension skills through an interactive approach?

b) What is the student response to improving reading comprehension skills through an interactive approach using short stories?

\section{Literature Review}

The importance of reading comprehension ability will help many students in interpreting the contents of the text content because it is not just reading but must know the message to be conveyed the author in the text. There are four main skills in English including writing, speaking, listening and reading is one of the skills that must be mastered. Reading is an important activity in language class, not only as a source of information and to expand one's knowledge [3]. With the ability to understand reading text, information and knowledge transformation will be occurred to the reader depending on the context of what is being read. In this case the reader will be got a lot of results from their interactions with language offerings, either through text or printed books and so forth. When someone was reading, he must be able to understand and then summarize it. Reading is a process of being able to recognize words and integrate them into word meanings and become sentences and structures read [4]. From this definition that reading is a procedure of understanding and taking the importance of words, thoughts, ideas, ideas, and data that have been stated.

\section{A. Interactive Approach}

According to [5][6], Learning is a process of change in human personality, and the change is manifested in the form of increasing the quality and quantity of behavior such as increasing skills, knowledge, attitudes, habits, comprehension, skills, thinking power, and other abilities, while teaching instilling knowledge in students in the hope of understanding. Interactive learning model (interactive approach) is a student-oriented learning model (student centered), where students are directly involved in various types of learning activities in the room. It makes students interact with each other in doing and thinking (hands on and minds on) which results in direct feedback on the course material provided [7]. Then interactive learning models were designed so that students asked and found their own answers [8].

An interactive learning model is a learning model that allows interactive students with lecturers, classmates and media learning [9]. This learning model can handle individual differences in students, because students can progress according to their abilities without having to wait for their roommates. The learning process in the interactive learning model allows students to exercise the freedom to learn independently, without being interrupted by others and take a test for each discussion unit they have learned and move forward according to their abilities with the help and 
direction of lecturers, or repeat the learning process in the same unit until achieve minimal mastery in accordance with predetermined targets.

In general interactive approach has developed as a teaching strategy that allows students to engage in the full learning process that given courage to explore experiences, obtain information and build knowledge according to their own concepts both through group work techniques, interactive multimedia, experiments, history and so on.

\section{Methods}

This research was conducted at the South Aceh Polytechnic Campus by taking short stories lecture material as a trial material by using interactive approach teaching techniques to improve the ability of the second semester students in English subjects 2. Treatment by taking two classes, one experimental class, where in class this will be applied interactive approach techniques in the teaching process, while the other was no conventional treatment or learning techniques. This activity was carried out to find out which class was the most effective in absorbing teaching material and was able to explore its abilities. Furthermore the purpose of experimental research is not only to collect data and describe the data but also to find the causes and consequences [10]. In the experimental research also were to determine the effectiveness of a teaching method that was applied in the classroom and will be a reference to the next teaching system.

Correct experimental research is a study which is divided into two groups, namely the experimental class and the control class [11]. Where here the hypothesis will be tested whether the use of short stories with an interactive approach can improve students' English proficiency. The test begins by giving a pre-test and post-test, then forming a group of 4 people by providing reading comprehension material in the form of short stories, where each meeting was given different material with five meetings. Furthermore, the control class was not given any treatment, only distributed materials and they studied them individually. Each test that tested was given a value, and at the end of the meeting a given average score was obtained. At the end of the meeting the researcher gave a questionnaire to the students as material to analyze the lecture methods and materials that had been taught in the research activity.

\section{A. Interactive Approach}

Interactive learning model (interactive approach) is a student-oriented learning model (student centered), where students are directly involved in various types of learning activities in the room. It makes students interact with each other in doing and thinking (hands on and minds on) which results in direct feedback on the course material provided. Then interactive learning models were designed so that students asked and found their own answers.

An interactive learning model is a learning model that allows interactive students with lecturers, classmates and media learning. This learning model can handle individual differences in students, because students can progress according to their abilities without having to wait for their roommates. The learning process in the interactive learning model allows students to exercise the freedom to learn independently, without being interrupted by others and take a test for each discussion unit they have learned and move forward according to their abilities with the help and direction of lecturers, or repeat the learning process in the same unit until achieve minimal mastery in accordance with predetermined targets.

In general interactive approach has developed as a teaching strategy that allows students to engage in the full learning process that given courage to explore experiences, obtain information and build knowledge according to their own concepts both through group work techniques, interactive multimedia, experiments, history and so on.

\section{B. Population and Sample}

Population is the number of research subjects, where the sample is part of the population studied in a study [12]. Here the researcher will be taken the research population to students who study in the second semester at the Department of Computer Engineering, South Aceh Polytechnic. While the sample is part of the overall population. Population is the entire subject of research, 
where the sample is part of the population [13]. Where the number of samples were 29 people divided into two classes, namely class A and class B.

\section{Instrument}

Instrument is a test tool that tested on samples to be collected data that you want to be obtained as raw data information and then it was processed into recommended data after going through research methods. The research tools include;

\section{Test}

Tests are an important contributing tool for processing and evaluating students, curriculum and teaching methods [14]. Where this test will help researchers to be measured the ability of students on reading comprehension skills, both before and after it was in the form of pre-test and post-test. This pre-test was given to students at the beginning of the meeting; the activity was to find out the student's initial ability about reading with 10 questions that must be answered by students. Then the post-test was given at the end of the meeting after being treated with the use of interactive approach with a group work model. This activity was an evaluation of the teaching model that has been taught, whether successful or not.

\section{Questionnaire}

One of the tools used in this research was a questionnaire to evaluate all the obstacles students face in given subjects, especially the ability to read comprehension by analyzing the answers given in the form of percent [15].

The formula $P=f / n \times 100$

Where;

$\mathrm{P}=$ Percent

$\mathrm{f}=$ Frequency

$\mathrm{n}=$ Amount

\section{Results and Discussions}

At this stage the data collection was carried out, namely the experimental class and the control class, totaling 29 people consisting of semester 2 students in the Computer Engineering Department of South Aceh Polytechnic. The following are the results of obtaining student grades as follows;

Table 1. Pre-test and post-test scores of experimental and control

\begin{tabular}{|c|c|c|c|c|c|c|}
\hline \multicolumn{4}{|c|}{ Experimental class } & \multicolumn{3}{|c|}{ Control class } \\
\hline \multirow{2}{*}{ No } & \multirow{2}{*}{ Sample } & \multicolumn{2}{|c|}{ Results } & \multirow{2}{*}{ Sample } & \multicolumn{2}{|c|}{ Results } \\
\hline & & Pre-Test & Post-Test & & Pre-Test & Post-Test \\
\hline 1 & $\mathrm{SH}$ & 60 & 75 & PM & 55 & 60 \\
\hline 2 & KM & 55 & 75 & $\mathrm{HM}$ & 45 & 60 \\
\hline 3 & DM & 45 & 70 & RA & 50 & 65 \\
\hline 4 & MR & 55 & 75 & VA & 45 & 60 \\
\hline 5 & $\mathrm{AD}$ & 60 & 80 & $\mathrm{CM}$ & 55 & 60 \\
\hline 6 & $\mathrm{AG}$ & 45 & 75 & FRS & 65 & 65 \\
\hline 7 & FR & 60 & 80 & CKZ & 60 & 70 \\
\hline 8 & $\mathrm{AL}$ & 50 & 80 & MFT & 60 & 65 \\
\hline 9 & AN & 65 & 85 & LH & 55 & 65 \\
\hline 10 & MY & 50 & 90 & AN & 55 & 65 \\
\hline 11 & MO & 60 & 75 & YP & 45 & 60 \\
\hline 12 & $\mathrm{SN}$ & 55 & 80 & NR & 50 & 60 \\
\hline 13 & IR & 60 & 85 & $\mathrm{ZA}$ & 50 & 60 \\
\hline 14 & RH & 60 & 85 & $\mathrm{ZU}$ & 60 & 70 \\
\hline 15 & $\mathrm{MN}$ & 45 & 75 & & & \\
\hline & $\sum$ & $\Sigma 825$ & $\Sigma 8610$ & & $\Sigma 695$ & $\Sigma 950$ \\
\hline
\end{tabular}




\begin{tabular}{lllll} 
Mean & 55 & 77,67 & 49,64 & 67,87 \\
\hline
\end{tabular}

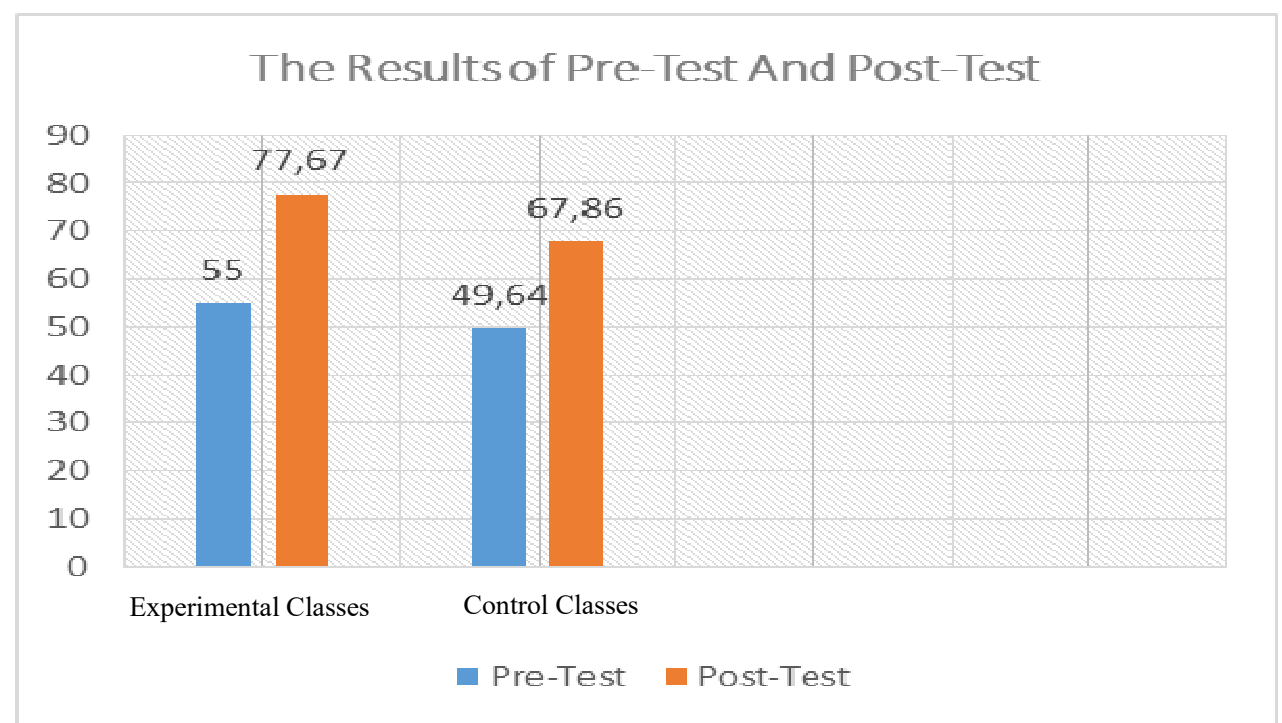

Figure 1. The results of the pre-test and post-test values of the experimental class with the control class in the form of bar charts

From this Figure 1 was explained the average value of the experimental class pre-test 55, while the post-test 77.67 and then we can be seen the pre-test control class 49.64 while the post-test 67.86. So if we compare and analyze the scores between the two classes, the value of the post-test $=77.67-67.86=9.81$ means that there was a difference of 9.81 and can be recommended for using short stories in teaching reading comprehension with interactive approach models got a significant increase in the ability of students in reading comprehension. Then the results of the questionnaire of 15 students who were asked to respond, 13 people answered very well with a weight of 4,2 people answered well with a weight of 3,0 people answered enough with a weight of 2 , and 0 people who answered less with a weight of 1 .

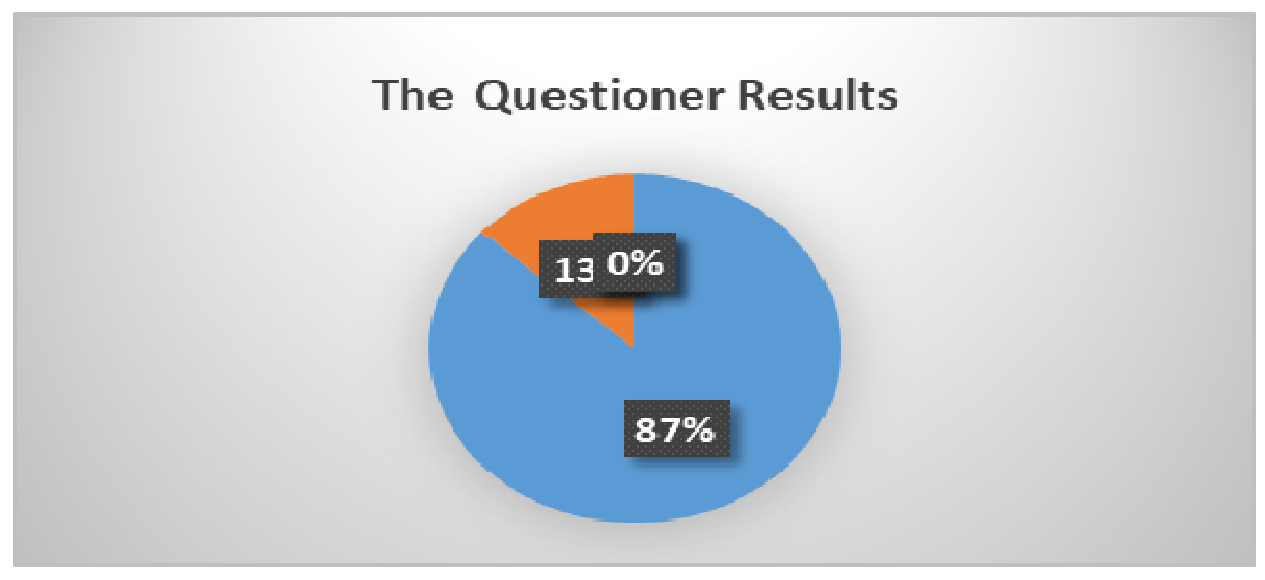

Figure 2. Results of analysis of student responded to the interactive approach teaching model in reading comprehension subjects by using short story lecture material.

According to the Figure 2 was explained that $87 \%$ of students experienced improved comprehension reading skills through an interactive approach model very well and the remaining $13 \%$ responded well. As well as answering enough options and less as much as $0 \%$. 


\section{Conclusions}

From the results of this study it can be obtained that the experimental class has increased reading comprehension skills after using short story lecture material with interactive approach teaching models. The average pre-test $=55$, while the post-test 77,67 . Whereas when compared with the control class only got a pre-test value $=49,64$ and post-test $=67,86$. So if we compare and then analyzing the scores between the two classes obtained by the post-test score of 77.67$67.86=9.81$, means that there was a difference in the numbers reaching 9.81 and it can be recommended that, used the material of short story in teaching reading comprehension with interactive models approach can be improved students' reading comprehension skills rather than using conventional learning models.

Meanwhile, from the questioner data were received the good responses from students on the lecture material and teaching models that have been done, which have helped to develop selfconfidence, cooperation, self-ability and group work. Of course this research was far from perfection and needs to be improved in the future with other methods while still providing motivation to students to be continued to develop their learning, especially reading comprehension skills.

\section{References}

[1] Brown, H. 2008. "Teaching by Principle an Interactive Approach to Language Pedagogy". New York: Pearson Education. p.358

[2] Cooper, J. David. 2000. "Literacy Helping Children Construct Meaning". Boston: Houston Mifflin

[3] River, W. 1996. "The Reading Skill Teaching Foreign Language Skill”. Chicago: Chicago University Press

[4] Sandjaja, S. 2006. Pengaruh Keterlibatan Orang Tua Terhadap Minat Baca Anak ditinjau dari Pendekatan Stres Lingkungan. www.google.com

[5] Fajri, Nur, Asmaidi. 2020. Application of Kumon Learning Model to Improve Student Learning Outcomes in Economic Math Subject. Jurnal Inovasi Teknologi dan Rekayasa, 5(2), pp. 85-91, July-December 2020, ISSN 2581-1274. Politeknik Aceh Selatan

[6] Asmaidi, Lovita, Oktalia. T, Khairuman. 2019. Effectiveness of the Application of Cooperative Learning Models Type Group Investigation on Discrete Mathematics Courses at Informatics Engineering Study Program of Polytechnic of South Aceh. Jurnal Inovasi Teknologi dan Rekayasa, 4(1), pp. 23-30, June 2019, ISSN. 2581-1274. Politeknik Aceh Selatan

[7] Hancock, O. 1987. "Reading Skills for College Students". New Jersey: Prentice-Hall Press

[8] Kagan, L. 2005. "Cooperative Learning”. New York: Prentice-Hall Press

[9] Adam, J., Carlson, H., \& Hamm, A. 1990. "Teaching Reading by Using Cooperative Learning". New Jersey: Harper Collins College Publisher

[10] Surachmad. 1990. Metode Penelitian. Jakarta: PT. Rineka Cipta. p.64

[11] Arikunto, S. 2006. "Prosedur Penelitian Suatu Pendekatan Praktek". Jakarta: PT Rineka Cipta. p. 17

[12] Arikunto. 1997. "Metode Penelitian”. Jakarta: Gramedia Group. p.25. 1997

[13] Arikunto, S. 2006. "Prosedur Penelitian Suatu Pendekatan Praktek". Jakarta: PT Rineka Cipta. p. 130

[14] Sudjana. 2002. "Pengantar Statistika". Bandung: Tarsito Press

[15] Kubiszyn, J., \& Boriszyn, A. 2001. "Research Methodology”. New York: Practice-Hall Press. 